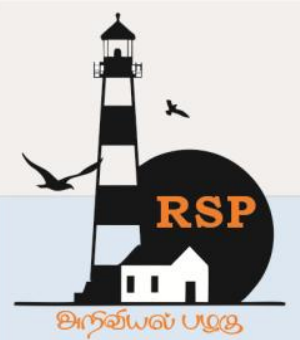

INTERNATIONAL RESEARCH JOURNAL ON ADVANCED SCIENCE HUB

ISSN : $2582-4376$
Open Access

RSP SCIENCE HUB

(The Hub of Research Ideas)

Available online at www.rspsciencehub.com

Special Issue of First International Conference on Advancements in Management, Engineering and Technology (ICAMET 2020)

\title{
Impact of COVID-19 on Education
}

Yeshi Ngima ${ }^{1}$, Dorjee Tsering ${ }^{2}$

${ }^{1}$ Assistant Professor, Department of Commerce, Saint Claret College, Ziro, Arunachal Pradesh, India

${ }^{2}$ Assistant Professor, Department of Commerce, Saint Claret College, Ziro, Arunachal Pradesh, India dorazzz.dt@gmail.com ${ }^{2}$

\begin{abstract}
The world has witnessed a standstill moment because of outbreak of coronavirus not sparing anyone across ethnicity, be it rich or poor, black or white, east or west, north or south. The pandemic has affected various sectors, education being one of it. According to UNESCO, close to 900 million learners have been affected by the closure of educational institutions. (11) Due to this pandemic, the educational institutions have to move from conventional mode of parting education to online mode. The research paper highlights advantages and disadvantages of imparting education through online mode during the pandemic situation.
\end{abstract}

Keywords: COVID, Education, Pandemic, ICT, Impact, Teaching, Learning, Economy, online teaching.

\section{Introduction}

Every day and every second of our life seem to be a mystery these days. The whole world is in a total turmoil because of the outbreak of Coronavirus which was first identified as $\beta$-Coronavirus occurred in Wuhan, China [1]. Coronavirus also known as COVID-19, has brought the world into a battle of life and death. Coronavirus is a $\beta$ Coronavirus, which is enveloped non-segmented positive-sense RNA virus [2]. The symptom shown in COVID patients are mostly mild respiratory symptom similar to a common cold [3]. The COVID-19 pandemic has not only brought panic amongst the people but it has also brought a drastic change in the economy, not sparing even the most powerful nation, the United State of America. The term coronavirus itself has become a threat among the people. It has also affected the communities and societies across the globe. Economically it has affected the common people. Due to the lockdown, people from every field of work ranging from White Collar job to a simple labourer, who faced hardship as they either became jobless with no work around for sustainable. Uncertainty of earning livelihood has affected the basic amenities which are essential for survival and also affected the world's economy to a great extent. The Pandemic has affected the economy severely which was never witnessed in the history of the World Economy. There had been a fall in the economy during the greatest depression of 1929 which lasted till 1933 [4]. Even the developed economies around the world are battling to overcome the financial difficulties that this pandemic has caused. The circumstance is terrible to such an extent that even the prominent leaders around the world are oblivious to come up with a fool proof and lasting solution. According to data released by National Statistical Office (2020), estimate for GDP for the first quarter (April to June) of 2020-21 accounted contraction of 23.9 percent as compared to 5.2 percent growth in quarter one in 2019-20 [5].

The Covid-19 pandemic has tremendously hit 


\section{www.rspsciencehub.com}

India, particularly since numerous divisions were at that point confronting an emergency when the infection storm hit. If not all, key divisions that make up a bigger segment of India's GDP have been made totally or incompletely out of move [6]. Reports of employment misfortunes, unpaid leaves and different concerns are being accounted consistently. Centre for Monitoring Indian Economy (CMIE) information shows how joblessness in India spiked from the month of April [7]. The circumstance is relied upon the improvement throughout the following months.

Amidst all this, there are six sectors that has been affected the most. [7]

- MSME Sector

- Tourism and Hospitality Sector

- Aviation Sector

- Automobile Sector

- Real Estate Sector

- Educational Sector.

But in this research paper, we will focus exclusively on Education Sector.

Objectives:

The study has been conducted with three objectives in mind

To enlighten the impact of COVID-19 on education.

To highlight various advantages of online mode of education.

To enlist some drawbacks which are associated with online mode of imparting education

\section{Methodology:}

For the purpose of this study, data and information has been collected from various secondary sources. It has been compiled from various books, online articles and some prominent journals. The information presented in current study are collected from various reports prepared by national and international agencies on COVID-19 pandemic. Information are collected from various authentic websites.

\section{The impact of Covid-19 on Education.}

As we all know that the coronavirus is a lifethreatening disease which has claimed millions of lives across the globe and it has also crucially affected all the educational institutions like that of schools, colleges and universities whose functions were abruptly halted as the Government of India announced complete nationwide lockdown to prevent the spread of the virus (24rd of March, 2020). According to UNESCO, close to 900 million learners have been affected by the closure of educational institutions [8-12]. On one hand this shutdown helped to reduce the death rate by social distancing but on the other hand all the workers like that of the teachers are facing economic uncertainty. Students who never experienced home schooling before are forced to be tutored and home schooled by parents. Even the parents are experiencing the whole new role, i.e. the role of a teacher as they had to step in the shoes of professional academicians. Apart from drastic change in normal life of society, the student's normal way of schooling too has been jeopardized in many ways such as; learning with peer, group discussions, brainstorming sessions, practical experiments and important events, co-curricular and extra-curricular activities which play a vital role to enhance the metal and physical growth of students. Due to this pandemic, we had to move from conventional educational system to online mode [13]. Online classes have both advantages and disadvantages and we will discuss them both.

\section{Advantages of online classes:}

- Convenience

- Flexibility

- Cost-Effective

- Fun and easy

- Availability of Resources

- Personalized Guidance

- Availability of Instructor

- Group Communication

- Accessibility

- Quick Delivery of Lessons

- Less Impact on Environment

- Feedback and Assessment

- Improves retention quality

- Technical Skills

- Improves Self Discipline

Online classes are more convenient than that of class room teaching. This is because the students are at home and their environment is so familiar that they are at ease. They do not have the inner fear that sometimes makes them dull at learning in class room teaching environment. Students are found to be more flexible when they attend online classes. This is because they are in a place that is close to them and so they tend to be more attentive 
and active in their participation [9]

Online classes are cost effective as the students are at home and they do not have any maintenance or transport or miscellaneous charges that is actually required in conventional classes [8]. All the resources that the students require are all easily available and so it makes it easier for them to learn [10. In a classroom environment, a teacher cannot focus on all the students at the same time but in online classes the teacher can have one on one session with the students. This play the role of removing the embarrassing situation, especially introvert students, which does not happen in conventional classroom as the students has to face his peers while clearing his individual doubts and questions. Availability of the teacher in online classes is one of the important factors as it works as an advantage in making the students feel that they are given priority while conducting sessions [8]. We are living in a world that has given us the gift of Information and Communication Technology which when integrated with education system can boost up the teaching-learning process to a different dynamic scope [13]. At any given point of time the teacher can mention his or her availability which in turn will be very fruitful and valuable for the students. In a class room environment, students are very easily prone to distractions therefore leading to miscommunication and misinterpretation of any given topic; hence paralyzing a good communication progression. Online classes give the flexibility in managing sessions with students with no time-bound restrictions which becomes second important advantages of online teachinglearning process.

The students can easily access to all the materials that they need as per their syllabus. The teachers can quickly deliver the lessons without any interruption and at the same time they can create forum for an open discussion and provide questions and assignments at the same time. The pandemic has changed the course of normalcy in Education Sector but at the same time the online teaching-learning process has indirectly made the teacher-student to help in healing the environment with less usage and hassle of paper work. In this pandemic, other such resources such as transportation, fuel, accommodation and costeffective materials has been minimized. This results in judicious use of resources having less impact on the environment [11].

Feedback and assessments are also made easy by online classes [14]. All the classes and seminars can be recorded and accessed repeatedly as and when required by the students at any given point of time. One of the best advantages of online class is that students can improvise on their technical skills [8]. Finally, it improves the self-discipline of the students [14].

Even though there are many advantages, still the disadvantage has to be taken into account.

Disadvantages of online classes:

- Online student feedback is limited

- Online Learning can cause social isolation

- Online Learning requires strong selfmotivation and time management skills.

- Lack of communicational skill development in online students.

- Cheating prevention during online assessments is complicated.

- Online instructors tend to focus on theory rather than practice.

- Online Learning lacks interpersonal communication.

- Online Learning is limited to certain disciplines.

- Online learning is inaccessible to the computer illiterate population.

- Lack of accreditation \& quality assurance in online education.

The important factor of disadvantage of online teaching-learning process is that there is limited scope of student's feedback [14]. Online classes can cause social isolation [15-20]. The students have no space for communication among their peer groups. They come online when their classes start, they attend the session and then they logout. Hence, they have no time to communicate with one another which in turn causes social isolation. With these classes the students have no room for self-motivation, as it becomes a monotonous routine to $\log$ in and $\log$ out but the message conveyed and the intake of the lesson or the massage is uncertain. When the students attend school, they have a disciplined life. They have to come to school on time and they have to follow certain rules and regulation. But when it comes to online classes, they lack the time management skill 
and ethical conduct, which is very important in a student's life.

When it comes to online classes, students lack active communication skills with other peers. In schools, the students communicate with their teachers and peers which is absent in online mode [16]. Interpersonal communication is must to improve day to day social life as the saying goes "Man is by nature a Social Animal- Aristotle". Since all the assessments are done online the prevention of malpractice is at stake. This is because the teachers cannot do anything other than instruct. Students on the other hand are staying in their own comfortable zone which in turn makes it easier for them to indulge in such unethical activities, which will affect their long-term learning process. [21-27]

Online classes are basically theoretical. The teachers can only lecture on the topic and they cannot practically teach them [8]. The students on the other hand can only learn the theory part of the lessons and the practical part is left out. Face to face communication is also not possible with the online classes. Online teachings are limited, the teachers nor the students can do any practical or research works. Even though we are living in a modern world, there are many who lives below the poverty line. Not all are literate. One cannot deny the fact that there are still many people who are not well familiar with the modern equipment and latest technologies and those who could not afford to buy them, which creates disparity amongst students. Recently in a report covered by NDTV, a student, residing in Malappuram district of Kerala, committed suicide by torching herself to death because her family could not afford a smartphone for her online classes [12]. Such cases of students taking drastic steps of committing suicide were reported from across the country.

Everyone does not have the privilege to afford gadgets for their online classes and many students are facing hurdles of bad network connectivity in this pandemic situation [11]. Finally, the quality education that the educational institution wants to impart to their students cannot be fulfilled to the maximum level because of such prevailing issues. With this all the educational institutions have no other options but to go on with online classes. Before COVID, when students were going to school, they had certain curriculum which had to be followed and in turn it helped them not only in academic field but also in extracurricular activities to enhance their skill development. But post COVID, the educational institutions are adapting to new ways of imparting education by integrating latest Information and Communication Technologies for teaching learning process [13].

\section{Discussion and Conclusion}

The educational institution has a great role to play in boosting the country's economy. It has resulted in the great downfall of the economy. Educational institutions are facing a big crisis economically. What can be done to increase the economy in such a situation? Even to find a solution for this question seems to be impossible, because it is not just an economic loss but question of life and death. The only solution is to have social distancing and to bring out some creative measures to impart quality education. Not only the educational institutions, but also the students are facing massive problem coping with their studies. Only a school environment would be a best place for the students to learn. Their interest on their studies are all decreasing since they are getting used to the current situation. Global coordination and cooperation are the need of the hour to come up with best scientifically proven COVID-19 vaccine for the world. This could be the only measure to slow down the spread of the virus and also to regain the economic status which has shaken the world. It has to be a fresh start for the economy and the life of the upcoming generation.

\section{References:}

[1].Guo, Y. R., Cao, Q. D., Hong, Z. S., Tan, Y. Y., Chen, S. D., Jin, H. J., Tan, K. S., Wang, D. Y. and Yan, Y. (2020). The origin, Transmission and clinical therapies on coronavirus disease 2019 (COVID-19) outbreak-an update on the status. Military Medical Research. 7(11), 1-10.

[2].Zhu N, Zhang D, Wang W, Li X, Yang B, Song J, Et Al. (2020). A novel coronavirus from Patients with Pneumonia in China, 2019. N Engl J Med. 2020;382(8): 727-33.

[3]. Yin Y. and WunderinkRg. (2020). MERS, SARS and Other Coronaviruses as causes of Pneumonia. Respirology. 2018;23(2): 130-7

[4].Crafts, N. and Fearon, P. (2010). Lessons from the 1930s Great Depression.Oxford Review of Economic Policy. 23(3), 285-317. 


\section{www.rspsciencehub.com}

[5]. National Statistical Office. (2020). Press Note on Estimates of Gross Domestic Product for the First Quarter (April-June) 2020-21. Ministry of Statistics \& Programme Implementation, Government of India.

[6].Dev, S. M. and Sengupta, R. (2020). COVID19: Impact on Indian Economy. Indira Gandhi Institute of Development Research, Mumbai. WP-2020-013.

[7]. [Centre for Monitoring Indian Economy (CMIE). (2020). Retrieved from https://www.cmie.com/kommon/bin/ sr.php?kall=warticle \&dt=2020-05 05\% 2008:22:21\&msec $=776$. Retrieved on 1 st October 2020

[8].Jena, P. K. (2020). Impact of Pandemic COVID-19 on Education in India. Purakala, 31 (46): 142-149, ISSN:0971-2143.

[9].UNESCO- International Institute for Higher Education in Latin America and Caribbean (IESALC). (2020). Covid-19 and higher education: Today and tomorrow. UNESCO. Retrieved on 18th June 2020.

[10].Association for the Development of Education in Africa. (2020). Delivery

Education at Home in African Member States amid the COVID-19 pandemic: Country Status Report. ADEA. Abidjan.

[11].Nicolaa, M., Alsafib, Z., Sohrabic, C., Kerwand, A., Al-Jabird, A., Iosifidisc, C., Aghae, M. and Agha, R. (2020). The socioeconomic implications of the coronavirus pandemic (COVID-19): A review. International Journal of Surgery. 78, 185-193.

[12].NDTV. (2020). Unable to Join Online Classes, Kerala School Girl Commits Suicide: Cops. NDTV. Retrieved on 23rd September 2020.

[13].Kumar, D. N. S. (2020). Impact of COVID-19 on Higher Education. Retrieved from. https://www.highereducationdigest.c om/impact-of-covid-19-on-higher-education/. Retrieved on 18th June 2020.

[14].REANDA. (2020). Potential Impact of COVID-19 on Nepalese Economy. REANDA. Retrieved from http://www.reandainternational.com/News_Photo/pdf/P _i_C_N_E.pdf. Retrieved on 18thJune 2020.

[15].Wilson, S., Willianson, E., Clarke, C. and Morris, D. (2020). The Impact of COVID-19
Volume 02 Issue 10S October 2020

on Education and Children's Services. Retreivedfrom

https://www.ecdc.europa.eu/sites/def

ault/files/documents/COVID-19-schools-

transmission-August\%202020.pdf. Retrieved on 22nd June 2020.

[16].EY-Parthenon. (2020). COVID-19 Assessing

the impact on the education sector and looking ahead. Retrieved from.

https://www.ey.com/Publication/vw

LUAssets/ey-COVID-19-Assessing-the-

impact-on-the-education-sector-and-lookingahead/\%24File/ey-COVID-19-Assessing-theimpact-on-the-education-sector-and-lookingahead.pdf. Retrieved on 30th June 2020.

[17].World Bank Group: Education. (2020). The COVID-19 Crisis Response: Supporting tertiary education for continuity, adaptation, and innovation. World Bank. Washington DC. Retrieved on 18thJune 2020.

[18].Quacquarelli Symonds (QS). (2020). The Impact of the Coronavirus on Global Higher Education. Retrieved from.

https://www.qs.com/portfolio-items/theimpact-of-the-coronavirus-on-global-highereducation/. Retrieved on 18th June 2020.

[19].Croucher, G. and Locke, W. (2020). A postcoronavirus pandemic world: some possible trends and their implications for Australian higher education. Melbourne CSHE Discussion Paper. The University of Melbourne.

Melbourne.

[20].Burgess, S. andSievertsen, H. H. 2020 (1st April). Schools, skills, and learning: The impact of COVID-19 on education. Retrieved from. https://voxeu.org/article/impact-covid19-education. Retrieved on 17th June 2020.

[21].KPMG International. (2020). Higher Education in India and Covid-19: Impact on admission. Retrieved From. https://home.kpmg/in/en/home/insig hts/2020/05/further-insights-covid-19.html. Retrieved on 18th June 2020.

[22].Phillipson, J., Gorton, M., Turner, R., Shucksmith, M., McDermott, K. A., Areal, F., Cowie, P., Hubbard, C., Maioli, S., McAreavey, R., Monteiro, D. S., Newbery, R., Panzone, L., Rowe, F. and Shortall, S. (2020). The COVID-19 Pandemic and Its Implications for Rural Economies. Sustainability. Retrieved 
from https://www.mdpi.com/2071-

1050/12/10/3973. Retrieved on 18thJune 2020.

[23].Sintema, E. J. (2020). Effect of COVID-19 on the Performance of Grade 12 Students: Implications for STEM Education. EURASIA Journal of Mathematics, Science and Technology Education, 16(7) 1-6.

[24].Food and Agricultural Organisation of United States. (2020). COVID-19 and rural poverty: Supporting and protecting the rural poor in times of pandemic. FAO. Retrieved from. http://www.fao.org/3/ca8824en/CA8

824EN.pdf. Retrieved from 18th June 2020.

[25].Deloitte Center for Higher Education Excellence. (2020). COVID-19's impact on higher education: Strategies for tackling the financial challenges facing colleges and universities. Retrieved from https://www2.deloitte.com/content/d am/Deloitte/us/Documents/public-sector/usgps-covid-19-impact-on-higher-education.pdf. Retrieved on 18th June 2020.

[26].South Carolina Department of Health and Environmental Control (DHEC). (2020). Higher Education Guidance on Novel Coronavirus or COVID-19. Retrieved from https://www.dhec.sc.gov/sites/defaul t/files/media/document/Higher\%20E ducation $\% 20$ Guidance $\% 20$ on $\% 20 \mathrm{No}$ vel\%20Coronavirus\%20or\%20COVID-19.pdf. Retrieved on 18th June 2020.

[27].World Bank. (2020). Guidance Note on Education Systems' Response to COVID-19. Retrieved from http://pubdocs.worldbank.org/en/450 881585235950757/COVID19-EducationSector-Guidance-Note-March26.pdf. Retrieved on 18th June 2020. 